
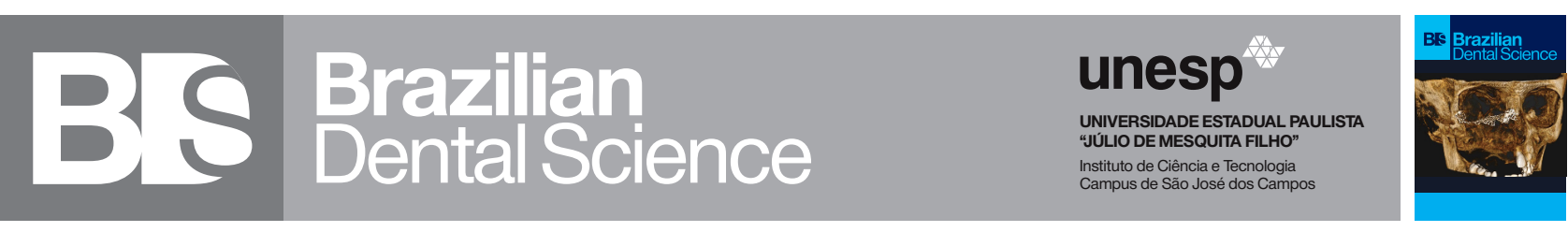

\title{
Evaluation the Effect of Different Antioxidants Applied After Bleaching on Teeth Color Stability
}

Avaliação do efeito de diferentes antioxidantes aplicados após o clareamento na estabilidade da cor dos dentes

\author{
Alperen DEGIRMENCI ${ }^{1}$, Emine KARA ${ }^{2}$, Beyza Unalan DEGIRMENCI ${ }^{3}$, Mutlu OZCAN ${ }^{4}$ \\ 1 - Van Yuzuncu Yil University - Faculty of Dentistry - Department of Restorative Dentistry - Van - Turkey. \\ 2 - Ministry of Health - Bursa Oral and Dental Health Center - Bursa - Turkey. \\ 3 - Van Yuzuncu Yil University - Faculty of Dentistry - Department of Prosthodontics - Van - Turkey. \\ 4 - University of Zürich - Center for Dental and Oral Medicine - Division of Dental Biomaterials - Clinic for Reconstructive Dentistry - \\ Zürich - Switzerland.
}

\section{ABSTRACT}

Objective: Vital bleaching is a popular treatment option for discolored teeth; but at post-treatment stage, loss of adhesion is highly reported. Literature focused on antioxidant application for the answer of this issue. The aim of this study was to compare the effects of six different antioxidants on color stability of bleached teeth. Material and Methods: This study included total of 84 extracted intact non-carious lower incisors. 35\% hydrogen peroxide was applied on the labial surfaces of specimens in accordance with manufacturer's instructions. The bleached teeth were divided into 7 groups. No antioxidants were applied to the control group. For the experimental groups, the following antioxidants were applied for 10 minutes each: $5 \%$ proanthocyanidin, $5 \%$ sodium ascorbate, $5 \%$ lycopene, $\% 5$ green tea, $\% 5$ white tea and $\% 5$ a-tocopherol. CIE L*, a* and b* values of the teeth were measured by a spectrophotometer. One-way ANOVA was used to determine the differences among the groups. Multiple comparisons were examined with Tukey HSD. Results: The one-way ANOVA test revealed a statistically significant difference between the groups $(p<0.005)$. Highest color change was observed in lycopene group and the lowest in green tea group. Conclusion: Proanthocyanidin, white tea and green tea could be considered as post-bleaching antioxidant alternatives based on their herbal nature.

\section{KEYWORDS}

Green Tea; Lycopene; Proanthocyanidin; Alphatocopherol.

\section{RESUMO}

Objetivo: O clareamento vital é uma opção popular de tratamento para dentes descoloridos, mas na fase póstratamento, a perda de adesão é altamente relatada. A literatura enfocou a aplicação de antioxidantes para a resposta desta questão. O objetivo deste estudo foi comparar os efeitos de seis diferentes antioxidantes na estabilidade da cor de dentes clareados. Material e Métodos: Este estudo incluiu um total de 84 incisivos inferiores extraídos, intactos e não cariados. Peróxido de hidrogênio a 35\% foi aplicado nas superfícies labiais dos espécimes de acordo com as instruções do fabricante. Os dentes clareados foram divididos em 7 grupos. Nenhum antioxidante foi aplicado ao grupo controle. Para os grupos experimentais, os seguintes antioxidantes foram aplicados por 10 minutos cada: proantocianidina a $5 \%$, ascorbato de sódio a $5 \%$, licopeno a $5 \%$, chá verde a $5 \%$, chá branco a $5 \%$ e $\alpha$-tocoferol a $5 \%$. Os valores $\operatorname{CIE} \mathrm{L} *, \mathrm{a} * \mathrm{e} \mathrm{b} *$ dos dentes foram medidos por um espectrofotômetro. ANOVA um fator foi usada para determinar as diferenças entre os grupos. As comparações múltiplas foram examinadas com Tukey HSD. Resultados: O teste ANOVA revelou uma diferença estatisticamente significativa entre os grupos ( $p<0,005)$. A maior mudança de cor foi observada no grupo do licopeno e a menor no grupo do chá verde. Conclusão: Proantocianidina, chá branco e chá verde podem ser considerados como alternativas antioxidantes pós-clareamento com base em sua natureza fitoterápica.

\section{PALAVRAS-CHAVE}

Chá verde; Licopeno; Proantocianidina; Alfatocoferol. 


\section{INTRODUCTION}

$\mathrm{T}$ he most common treatment option in teeth coloration is vital bleaching [1]. This method is reliable and well-known and has conservative and acceptable results. The commonly preferred bleaching agents are the concentrations of carbamide peroxide (35-37\%) and hydrogen peroxide (30-35\%) [2]. The mechanism of bleaching agents is based on oxidation-reduction reactions. The chemical process converts organic material into carbon dioxide and water. This reaction releases oxygen, which is a highly reactive free radical. This reaction creates a bleaching effect by penetrating the porosities of the enamel and converting the high-molecularweight organic molecules in enamel prisms into low-molecular-weight compounds [3].

However, dental bleaching agents have several side effects, including hypersensitivity, reduction of enamel micro-hardness, gingival irritation, micro-morphological defects in dental hard tissues, and loss of adhesion/ retention in post-treatment restorations [2]. Fluoride application is recommended after bleaching to repair demineralized lesions in many studies $[4,5]$. Another recent alternative option for eliminating these side effects is the use of antioxidant agents $[6,7]$. Antioxidants absorb free oxygen radicals, thus increasing the oxidation/reduction reaction of the enamel surface [8]. The most commonly indicated antioxidants in dental researches include sodium ascorbate, ascorbic acid, catalase, and acetone $[8,9]$. Sodium ascorbate is a neutral, non-toxic and biocompatible material [10]. For this reason, it is the most preferred antioxidant by dentists for the elimination of peroxide and oxygen radicals that inhibit post-bleaching composite polymerization [11]. $\alpha$-tocopherol is an active component of the Vitamin $\mathrm{E}$ and this substance is a powerful antioxidant for the lipid phase of the human body [12]. It has been recently suggested for improving composite bonding following bleaching [13]. The beneficial effect of alpha-tocopherol solution is attributed, in addition to its antioxidant effect, to its alcoholic solvent [12]. With the inclusion of prominent medical antioxidants in dental literature, several new antioxidants have come into use in dental practice. Natural antioxidants, such as proanthocyanidin, white tea, and green tea with free radical scavenging ability that has been shown to be 50 times more potent than that of sodium ascorbate [14]. Proanthocyanidin (PAC) is a naturally occurring plant metabolite commonly found in fruits, vegetables, dried nuts, seeds, flowers, and tree barks. PACs, often used as natural antioxidants and free radical scavengers, have proven to be safe in various clinical applications and as dietary supplements [15]. Grape seed extract is a rich source of PAC and is reported to augment collagen-based tissues by improving collagen crosslinkers [16]. Proanthocyanidins obtained from grape seed extract were found to lower hyperglycemia and improve insulin levels in the blood while reducing pancreatic oxidative stress in diabetic rats [17]. Studies have reported the use of proanthocyanidins in the treatment of cardiovascular diseases and certain types of cancer including oral cancers [18]. PAC, obtained from cranberries, was found to inhibit surface-adsorbed glucosyltransferases and acid production of S. mutans [19]. White tea is obtained from an unfermented tea made from the new growth buds and young leaves of the plant [20]. Green tea is made from the Camellia sinensis plant [14]. Both white and green tea contains mainly flavanols or catechins, such as epigallocatechin gallate (EGCG), epigallocatechin (EGC), epicatechin gallate (ECG), and epicatechin (EC) [21]. The catechins can donate hydrogens from the hydroxyl groups in their structure, they have excellent antioxidant activities [22]. White tea has been related to beneficial effects on several diseases such as neurodegenerative and cardiovascular diseases, diabetes, obesity and basically, to every pathology involving oxidative stress [23]. Green tea have an ability to prevent cardiovascular disease, and reduce dentin erosion and periodontal inflammation [24]. Lycopene is an antioxidant included in routine adjunctive therapy by medical doctors after the discovery of its accelerating effect in wound healing in 1959, 
and also a carotenoid present in tomato extract [25]. Despite its known free radical scavenging ability (7), lycopene's efficiency after bleaching has never been evaluated by the researchers.

This study aims to compare the color change on teeth caused by six different antioxidants (sodium ascorbate, proanthocyanidin, lycopene, green tea, white tea, $\alpha$-tocopherol) applied after laser-activated vital bleaching procedure with $35 \%$ hydrogen peroxide and to examine their safety in terms of color stability.

\section{MATERIAL AND METHODS}

The study was approved by the Clinical Research Ethics Committee of Van Yuzuncu Yil University Faculty of Medicine (24.10.2017/04).

\section{Preparation of Specimens}

In the study, $\Delta \mathrm{E}_{002}$ is considered as main trait. From the previous studies [6], the standard deviation for $\Delta \mathrm{E}_{002}$ varies between 0.1 and 1. Thus, standard deviation was taken as 0,55 . For the $95 \%$ of confidence coefficient and approximately $80 \%$ power value, Type I error is 0,05 ( $Z$ value is 1,96 for the $5 \%$ type I error), the effect size was taken by the researcher as 0,3.

Based on this information, the necessary sample size was calculated by the equation

$$
\text { "n }=Z^{2} \times \sigma^{2} / d^{2 "}
$$

According to this equation, minimum sample size in each group was found as 12 [n = $\left(1.96^{2} \times 0.55^{2} / 0.3^{2} \cong 12\right]$. A total of 84 extracted intact non-carious mandibular incisor human teeth were included in the study. Fractures were detected with the transillumination method with the assistance of light-transmitting glass fibers, and cracked teeth were excluded from the study. Dental roots were removed from the cementoenamel junction with a diamond blade. The teeth were polished with pumice and separated from the residual tissues, and the remnants of pumice were washed away with clear water. The teeth were kept in an incubator at $37{ }^{\circ} \mathrm{C}$ for three days before bleaching. The specimens were embedded in silicone molds in groups of three.

\section{Bleaching Procedure}

All the bleaching procedures were performed by a single operator. Bleaching agent, including 35\% hydrogen peroxide, was applied on the labial surfaces of all 84 specimens according to manufacturer's instructions (Fotona Chairside Bleaching Gel, Fotona, Vilnius, Lithuania). A diode laser (Ezlase, Biolase, Irvine, USA) was used for the activation of the agent with 70 Joules energy in continuous wave mode with $3.5 \mathrm{~W}$ power for $2.5 \mathrm{~min}$. The operator applied the bleaching agent to the entire labial surface of the tooth and at least $1 \mathrm{~mm}$ thick. Then the agent was left on tooth surface without activation for 10 minutes.

\section{Preparation and Application of Antioxidants}

The teeth were randomly divided into seven groups after the bleaching application (Table I).

Table I - Study Group.

\begin{tabular}{|c|c|c|}
\hline Groups & Bleaching agent & Antioxidant \\
\hline Group Control $(n=12)$ & \%35 hydrogen peroxide & None \\
\hline Group Proanthocyanidin $(n=12)$ & $\% 35$ hydrogen peroxide & $\% 5$ proanthocyanidin \\
\hline Group Sodium Ascorbate $(n=12)$ & $\% 35$ hydrogen peroxide & $\% 5$ sodium ascorbate \\
\hline Group Lycopene $(n=12)$ & $\% 35$ hydrogen peroxide & $\% 5$ lycopene \\
\hline Group Green Tea $(n=12)$ & $\% 35$ hydrogen peroxide & $\% 5$ green tea \\
\hline Group White Tea $(n=12)$ & $\% 35$ hydrogen peroxide & $\% 5$ white tea \\
\hline Group $\alpha$-tocopherol $(n=12)$ & $\% 35$ hydrogen peroxide & $\% 5$-tocopherol \\
\hline
\end{tabular}

Five grams of each antioxidants in the form of powder was dissolved in $100 \mathrm{ml}$ of distilled water and stirred for $1 \mathrm{~min}$, and then, the solution was filtered [26]. The solutions were applied for 10 minutes using a syringe to place $0,02 \mathrm{ml}$ of each antioxidant: 5\% proanthocyanidin (GNC Proanthocyanidin, GNC, Inc. Nutra, Greenville, S.C., USA), 5\% sodiumascorbate (Alfasol Kimbiotek Corporation, Istanbul, Turkey), and 5\% lycopene (GNC Lycopene, GNC, Inc. Nutra,Greenville, S.C., USA), \%5 green tea (Emerald Gunpowder, Lipton, Istanbul,Turkey), \%5 white tea (Organic White Tea, Caykur, Istanbul, Turkey) and \%5 a-tocopherol (Alfasol Kimbiotek Kimbiotek 
Corporation, Istanbul, Turkey). Antioxidant applications were performed by another operator. Control group was left without any antioxidant applications. A soft toothbrush was used for making five back-and- forth movements over the tooth and washing with distilled and deionized water. They were then immersed in artificial saliva solution in containers and kept in incubator at $37^{\circ} \mathrm{C}$ for three days. And color measurements were repeated for the third time after the antioxidant applications.

\section{Spectrophotometric Color Analysis}

$L^{*}, a^{*}$ and $b^{*}$ values of the teeth were measured by a spectrophotometer (Spectroshade ${ }^{\mathrm{TM}}$ Micro, MHT, Verona, Italy). The teeth were placed on a neutral gray background, and the labial surfaces of the specimen were positioned for measurement. Color measurements were repeated before bleaching, after bleaching and antioxidant applications. Spectrophotometeric measurements were done by a single operator who was blinded to bleaching procedures and antioxidant applications The CIE L*, a* and $b^{*}$ values, obtained with a spectrophotometer, were computerized. The differences in shade according to the bleaching and antioxidant applications were calculated by quantifying $\Delta \mathrm{E}$ (mean color difference), with the use of $\Delta \mathrm{E}$ DE2000 $\left(\Delta \mathrm{E}_{00}\right)$ color difference formulas representing the distance from the measured values (L), (C), (h), (a), and (b) to the 3D space of two colors. The color change $\left(\Delta \mathrm{E}_{00}\right)$ was calculated using the following formula:

$\Delta E_{00}=\left[\left(\Delta L / K_{L} S_{L}\right)^{2}+\left(\Delta C / K_{C} S_{C}\right)^{2}+\left(\Delta H^{\prime} / K_{H} S_{H}\right)^{2}+R_{T}\left(\Delta C^{\prime} / K_{C} S_{C}\right)^{2}+\left(\Delta H^{\prime} / K_{H} S_{H}\right)^{2}\right]^{1 / 2}$

The following criteria were used to determine whether the obtained $\Delta \mathrm{E}_{00}$ values affect clinical usage and for the discernibility of color difference:

(a) $\Delta \mathrm{E}_{00}>1.77$ mean the magnitude that constitutes an unacceptable alteration to

dental aesthetics

(b) $\Delta \mathrm{E}_{00}=0.81$ mean the color difference can be visually detected [27].

Color changes due to bleaching application was recorded as $\Delta \mathrm{E}_{001} \Delta \mathrm{L}_{1}, \Delta \mathrm{a}_{1}$ and $\Delta \mathrm{b}_{1}$ while color change due to antioxidant application was noted as $\Delta \mathrm{EOO}_{2} \Delta \mathrm{L}_{2}, \Delta \mathrm{a}_{2}$ and $\Delta \mathrm{b}_{2}$.

\section{Statistical Analysis}

The data were analyzed using IBM SPSS V23. The suitability of normal distribution was evaluated with the Shapiro-Wilk test. And the data was normally distributed. One-way ANOVA was used to determine the differences among the groups. Multiple comparisons were examined with Tukey HSD since $\Delta \mathrm{E}_{001}$ values were homogeneous and other values were examined with Tamhane's T2.

\section{RESULTS}

There was a difference between the $\Delta \mathrm{E}_{001}$ mean values according to the groups $(\mathrm{p}=0.003)$. The reason of these statistical difference in both formula was based on that the mean value in the lycopene group was obtained lower than the proanthocyanidin and sodium ascorbate groups. After the bleaching procedure, color change of lycopene group was calculated as 0.846 for $\Delta \mathrm{E}_{001}$. There is no difference between other groups in terms of $\Delta \mathrm{E}_{001}$ ( $\left.\mathrm{p}>0.05\right) . \Delta \mathrm{E}_{001}$ mean values differ according to the groups ( $\mathrm{p}<0.001)$. The highest mean value was obtained in the lycopene group for both of the calculations (Figure 1). After lycopene applications, color change was calculated 11.712 for $\Delta \mathrm{E}_{002}$. That means the color change was visually distinguished by all observers. The average value in the $\alpha$-tocopherol group was obtained as 3.681 for $\Delta \mathrm{E}_{002}$ and the value obtained in this group differs from the others $(p<0,05)$. There is no difference between proanthocyanidin, sodium ascorbate, green tea and white tea and control groups ( $\mathrm{p}>0.05)$. (Table II).

$\Delta \mathrm{L}_{2}$ mean values differ according to the groups ( $\mathrm{p}<0.001)$. The lowest mean value was obtained in the lycopene group with -13.66. There is no difference between white tea and control, sodium ascorbate and green tea $(\mathrm{p}>0.05)$. There is also a difference between the groups in the mean values of $\Delta \mathrm{a}_{2}(\mathrm{p}<0.001)$. The highest mean value was obtained in the lycopene group with 13.1. The difference between the other groups is presented in Table II. $\Delta \mathrm{b}_{2}$ mean values also differ according to the groups $(\mathrm{p}<0.001)$. In $\Delta \mathrm{b}_{2}$ average values, the highest value is in lycopene group with 8.46. The mean value of $\alpha$-tocopherol also differs from other groups. 
Table II - Fracture modes of four one-step adhesive materials (\%).

\begin{tabular}{ccccccccc} 
& $\Delta \mathrm{L}_{1}$ & $\Delta \mathrm{a}_{1}$ & $\Delta \mathbf{b}_{1}$ & $\Delta \mathrm{E}_{001}$ & $\Delta \mathrm{L}_{2}$ & $\Delta \mathrm{a}_{2}$ & $\Delta \mathbf{b}_{2}$ & $\Delta \mathrm{E}_{002}$ \\
\hline $\boldsymbol{\alpha}$-tocopherol & $4.883 \pm 3.794 \mathrm{ab}$ & $-0.575 \pm 0.563$ & $0.033 \pm 1.058$ & $2.071 \pm 1.308 \mathrm{ab}$ & $-5.03 \pm 1.01 \mathrm{~d}$ & $2.67 \pm 0.67 \mathrm{~d}$ & $4.79 \pm 1.39 \mathrm{c}$ & $3.681 \pm 0.595 \mathrm{a}$ \\
\hline White Tea & $4.883 \pm 3.794 \mathrm{ab}$ & $-0.575 \pm 0.563$ & $0.033 \pm 1.058$ & $2.071 \pm 1.308 \mathrm{ab}$ & $0.23 \pm 0.22 \mathrm{a}$ & $-0.22 \pm 0.11 \mathrm{a}$ & $-0.03 \pm 0.08 \mathrm{a}$ & $0.254 \pm 0.106 \mathrm{~b}$ \\
\hline Control & $2.683 \pm 2.384 \mathrm{ab}$ & $-0.483 \pm 0.484$ & $-0.267 \pm 0.695$ & $1.297 \pm 0.794 \mathrm{ab}$ & $1.32 \pm 1.59 \mathrm{ab}$ & $-0.58 \pm 0.21 \mathrm{c}$ & $0.16 \pm 1.15 \mathrm{a}$ & $1.04 \pm 0.503 \mathrm{~d}$ \\
\hline Lycopene & $1.508 \pm 1.016 \mathrm{a}$ & $-0.525 \pm 0.347$ & $-0.342 \pm 0.593$ & $0.846 \pm 0.471 \mathrm{a}$ & $-13.66 \pm 2.98 \mathrm{c}$ & $13.1 \pm 2.96 \mathrm{~b}$ & $8.46 \pm 3.08 \mathrm{~b}$ & $11.712 \pm 1.992 \mathrm{c}$ \\
\hline $\begin{array}{c}\text { Proanthocy- } \\
\text { anidin }\end{array}$ & $6.6 \pm 3.49 \mathrm{~b}$ & $-0.517 \pm 0.537$ & $0.058 \pm 0.837$ & $2.525 \pm 1.347 \mathrm{~b}$ & $-0.46 \pm 0.26 \mathrm{~b}$ & $-0.01 \pm 0.28 \mathrm{a}$ & $-0.65 \pm 1.8 \mathrm{a}$ & $0.675 \pm 1.02 \mathrm{bd}$ \\
\hline $\begin{array}{c}\text { Sodium } \\
\text { Ascorbate }\end{array}$ & $6.525 \pm 3.534 \mathrm{~b}$ & $-0.908 \pm 0.557$ & $-0.108 \pm 1.069$ & $2.636 \pm 1.344 \mathrm{~b}$ & $-0.48 \pm 0.97 \mathrm{ab}$ & $-0.12 \pm 0.32 \mathrm{a}$ & $0.42 \pm 0.86 \mathrm{a}$ & $0.586 \pm 0.385 \mathrm{bd}$ \\
\hline $\begin{array}{c}\text { Green Tea } \\
4.883 \pm 3.794 \mathrm{ab}\end{array}$ & $-0.575 \pm 0.563$ & $0.033 \pm 1.058$ & $2.071 \pm 1.308 \mathrm{ab}$ & $0.16 \pm 0.12 \mathrm{a}$ & $-0.2 \pm 0.1 \mathrm{a}$ & $0.13 \pm 0.15 \mathrm{a}$ & $0.247 \pm 0.096 \mathrm{~b}$ \\
\hline $\mathbf{p}^{*}$ & 0.002 & 0.497 & 0.893 & 0.003 & $<0.001$ & $<0.001$ & $<0.001$ & $<0.001$
\end{tabular}

16

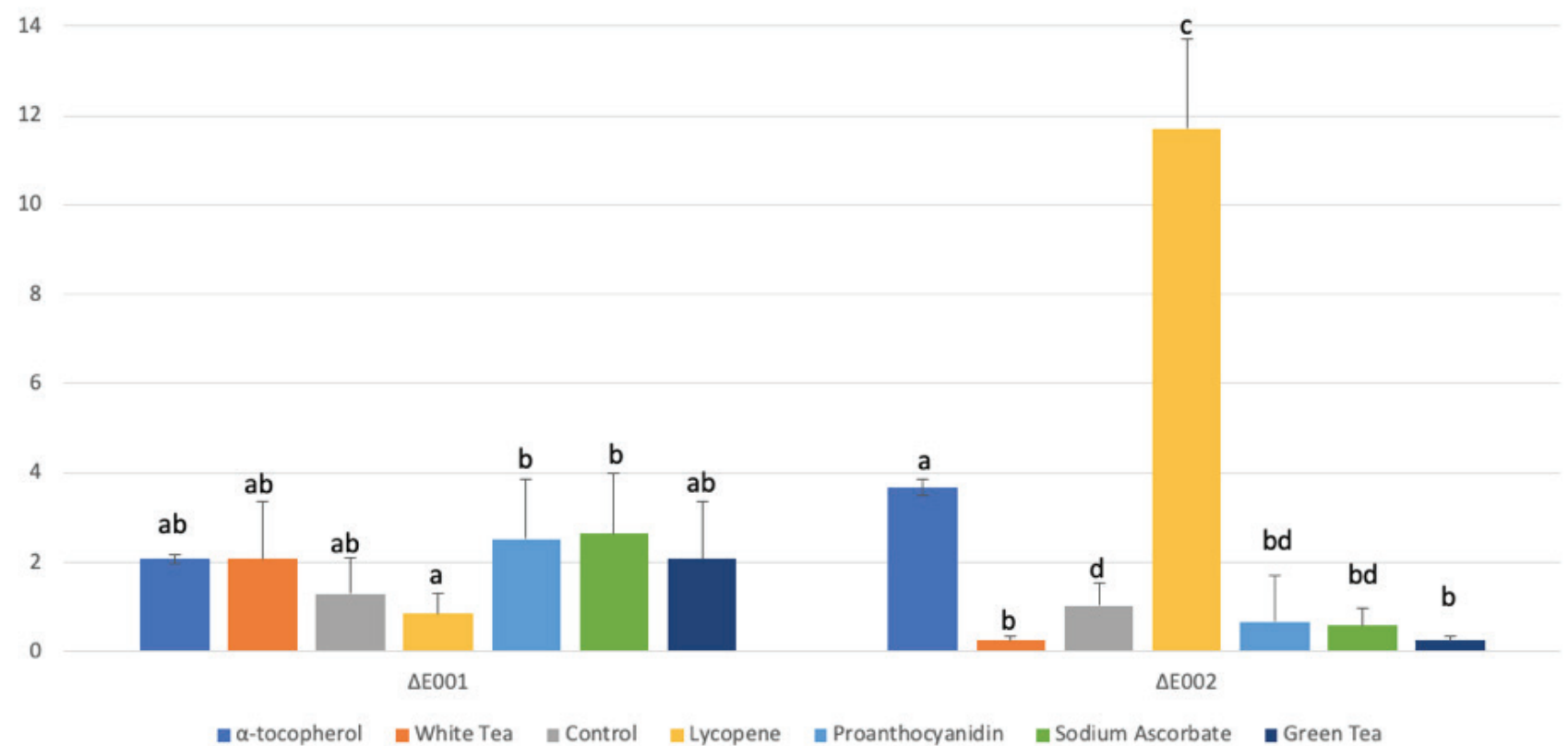

Figure 1- Average and deviation graphic of $\Delta \mathrm{E}_{001}$ and $\Delta \mathrm{E}_{002}$ according to the groups.

\section{DISCUSSION}

Dental aesthetics is an important issue. Tooth bleaching is one of the most preferred dental treatments. However, the most significant disadvantages of the procedure are the returning of the discoloration, repetition requirement of the bleaching treatment, hypersensivity and an undesired color result after the bleaching [28]. Diode laser of $940 \mathrm{~nm}$ is an effective adjunctive tool for reducing hypersensivity originated from high concentration $\mathrm{H} 2 \mathrm{O} 2$ bleaching gel [29] but adhesive restorations following tooth bleaching might be required in such cases. A minimum of 2 weeks waiting period is recommended in the literature for the success of adhesive restorations [30]. The reason for this recommendation is that the hydrogen peroxide degradation continues after bleaching, and thus, the produced free radicals inhibit resin polymerization and weaken adhesion [31]. Therefore post-bleaching antioxidant application has been preferred since 1993 [32]. 
Several studies examined the effect of postbleaching antioxidant applications on shear bond strength of composite restorations and as a result, they proved the positive effects of antioxidant applications [3, 10, 33]. However, there are limited studies in the literature that investigate the effects of antioxidants on color stability [6].

Sodium ascorbate is the most preferred and studied antioxidant in dental practice [34, 35]. Most of the studies investigated its postbleaching effects on bonding, and its positive effects were confirmed on shear bond strength [36]. However, there is only one study examining the effects of sodium ascorbate on post-bleaching tooth color. This study has evaluated tooth color change in 169 patients who were applied sodium ascorbate following the endo-bleaching procedure and reported the color change on the surface of the tooth. As a result, no difference was reported in terms of color stability between sodium ascorbate group and the control group, and the use of it was reported to be safe [37]. In this study, sodium ascorbate group showed similar color stability to the control group which was not applied any post-bleaching antioxidant. There was no statistically significant difference between the control and sodium ascorbate groups $(p>0.05)$. In this respect, the results of the present study are consistent with the literature.

The success of sodium ascorbate has led scholars to explore other antioxidants, and $\alpha$-tocopherol has become one of the primary dental research foci [13]. $\alpha$-tocopherol is most profusely found in nature and is responsible for the reversal of Vitamin E deficiency symptoms in humans [38]. Kavitha et al. evaluated the ten percentage $\alpha$-tocopherol, and it has shown high efficacy in shear bond strength reversal of enamel and dentin submitted to a homeuse bleaching treatment [39]. In 2009, Sasaki et al. compared the efficacy of two different antioxidizing agents in increasing the shear bond strength of bleached enamel and dentin, reporting that $10 \%$ a-tocopherol was successful, whereas $10 \%$ sodium ascorbate was not [12]. However, there is no study evaluating the effects of $\alpha$-tocopherol solution on color stability of bleached teeth. In this study, it was found that the application of $\alpha$-tocopherol solution provokes the discoloration which is clinically distinguished $\left(\Delta \mathrm{E}_{002}=3.681\right)$. And $\Delta \mathrm{L}_{2}$ values had decreased, $\Delta \mathrm{a}_{2}$ value was 2.67 and $\Delta \mathrm{b}_{2}$ value was 4.79 . These results can be explicated that after the application, tooth color was darkened, gone yellow and red. It can be correlated the naturel orange color of $\alpha$-tocopherolin. Later, the researchers turned their direction to natural antioxidants, and proanthocyanidine was one of the first to come to mind [8]. The main reason for this is that proanthocyanidin is easy-to-obtain from grape seed extract and has bonding properties even better than the antioxidants, which were proven to improve the bonding such as sodium ascorbate [40]. However, bond improvement is not the sole criterion for the use of post-bleaching antioxidants; they should also not have any negative effect on color stability. In their study, Taneja et al. found that grape seed extract reduces post-bleaching discoloration [6]. However, proanthocyanidin (PAC) was also included in this study, an active ingredient of grape seed extract and it was observed a significant color change in the related group in our results. In this respect, the results are not consistent with this study. This difference might be explained by the differences in the procedure, such as concentration and duration, which are known to affect bond formation results in antioxidant procedures [41, 42]. No significant change was observed in $\Delta \mathrm{L}_{2}, \Delta \mathrm{a}_{2}$ and $\Delta \mathrm{b}_{2}$ values. That indicates no yellowness or redness occured in tooth color and no study was found evaluating color stability following proanthocyanidin application in the literature.

Nowadays, researchers have a focus on white and green tea which have strong antioxidant capacity. But the main aim of this interest is evaluating the effects on bond strength of composite and bleached enamel or 
dentine $[14,35]$. In this study, the main goal is evaluating the effects on color stability and we found no difference between green tea, white tea and control groups based on $\Delta \mathrm{E}_{002}$ values ( $\mathrm{p}>0.05) . \Delta \mathrm{E}_{002}$ value was calculated as 2.071 after application of green tea and white tea. These results can be related with their colorless nature and no distinguishable color difference occurred. Due to the new focus, there are only few research that consider the effects of green tea on color stability of dental materials like lithium disilicate,zirconia based ceramics and composite resin etc $[43,44]$. But there is no study about the post-bleaching applications. When comparing the green tea, white tea is a subject of broad and current interest and studies are limited and focused it as a dentin bonding treatment agent [45]. Lycopene is a widely used antioxidant in medicine, and in the field of dentistry, its effects were examined only on periodontal healing $[46,47]$. In this study, the most substantial color change was reported in Lycopene group. Moreover, $\Delta \mathrm{L}_{2}$ values decreased while $\Delta \mathrm{a}_{2}$ and $\Delta \mathrm{b}_{2}$ values significantly increased. This result shows that the teeth in group 4 have darkened, became more yellow and redder. The redness may be associated with the red pigments in lycopene, as it is obtained from tomato extract. Its applicability to bleached teeth may be limited due to its significant effect on color stability; however, it may be useful to evaluate its effects on bond formation.

Limitations of this study could be listed as follows: assessing only one type of bleaching agent, and at one concentration level, not evaluating antioxidant form and application times and that no stratification approach was performed after the bleaching based color change to distribute the specimens equally in the antioxidant groups. Further antioxidant studies with clinical follow-up are required.

\section{CONCLUSION}

Proanthocyanidin, sodium ascorbate, green tea and white tea are reliable postbleaching antioxidants for maintaining color stability. The application of lycopene and $\alpha$-tocopherol after bleaching cannot be recommended even if they have an antioxidant effect, due to the significant color change they caused

\section{Conflict Of Interest Statement}

The authors declared no potential conflicts of interests with respect to the authorship and/or publication of this article. This research did not receive any specific grant from funding agencies in the public, commercial, or not-for-profit sectors.

\section{REFERENCES}

1. Khamverdi Z, Khadem P,Soltanian A, Azizi M. In-Vitro Evaluation of the Effect of Herbal Antioxidants on Shear Bond Strength of Composite Resin to Bleached Enamel.J Jent(Tehran). 2016;13(4):244-51. doi:

2. Vidhya S, Srinivasulu S, Sujatha M, Mahalaxmi S. Effect of grape seed extract on the bond strength of bleached enamel. Oper Dent. 2011;36(4):433-8. doi: 10.2341/10-228-L

3. Ozelin AA, Guiraldo RD, Carvalho RV, Lopes MB, Berger SB. Effects of green tea application time on bond strength after enamel bleaching. Braz Dent J. 2014;25(5):399-403. doi: 101590/0103-6440201300015

4. Torres C, Zanatta RF, Silva TJ, Borges AB. Effect of Calcium and Fluoride Addition to Hydrogen Peroxide Bleaching Gel On Tooth Diffusion, Color, and Microhardness. Oper Dent. 2019;44(4):424-32. do: 10.2341/18-113-L

5. KemaloğluH, Tezel H, ErgücüZ. Does post-bleaching fluoridation affect the further demineralization of bleached enamel? An in vitro study. BMC Oral Health. 2014;14:113- doi: 10.1186/1472-6831-14-113

6. Taneja S, Kumar M, Agarwal PM, Bhalla AS. Effect of potential remineralizing agent and antioxidants on color stability of bleached tooth exposed to different staining solutions. J Conserv Dent. 2018;21(4):378-82. doi: 10.4103/JCD. JCD 354 17

7. Arumugam MT,Nesamani R, Kittappa K, Sanjeev K, Sekar M. Effect of various antioxidants on the shear bond strength of composite resin to bleached enamel: An in vitro study. Journal of conservative dentistry: JCD. 2014;17(1):226. doi: 10.4103/0972-0707.124113

8. Torres C, Koga A, Borges A. The effects of anti-oxidant agents as neutralizers of bleaching agents on enamel bond strength. Brazilian Journal of Oral Sciences (ISSN: 1677-3217) Vol5 Num 16.2006;5.

9. Kaya $A D$, Turkun M. Reversal of dentin bonding to bleached teeth. Oper Dent. 2003;28(6):825-9. doi:

10. BulutH, Kaya AD, Turkun M. Tensile bond strength of brackets after antioxidant treatment on bleached teeth. Eur J Orthod. 2005;27(5):466-71. doi:10.1093/ ejo/cji044

11. Jung KH, Seon EM, Choi AN, Kwon YH, Son SA, Park JK. Time of Application of Sodium Ascorbate on Bonding to Bleached Dentin. Scanning. 2017;2017:6074253. doi:10.1155/2017/6074253

12. SasakiRT, Flório FM, Basting RT. Effect of $10 \%$ sodium ascorbate and $10 \%$ alpha-tocopherol in different formulations on the shear bond strength of enamel and dentin submitted to a home-use bleaching treatment. Oper Dent. 2009;34(6):746-52 doi: 
13. Thapa A, Vivekananda PA, Thomas MS. Evaluation and comparison of bond strength to $10 \%$ carbamide peroxide bleached enamel following the application of $10 \%$ and $25 \%$ sodium ascorbate and alpha-tocopherol solutions: An in vitro study. J Conserv Dent. 2013;16(2):111-5. doi:10.4103/09720707.108184

14. Berger SB, De Souza Carreira RP, Guiraldo RD, Lopes MB, Pavan S, Giannini $\mathrm{M}$, et al. Can green tea be used to reverse compromised bond strength after bleaching? Eur J Oral Sci. 2013;121(4):377-81. doi: 10.1111/eos.12062

15. Yamakoshi J, Saito M, Kataoka S, Kikuchi M. Safety evaluation of proanthocyanidin-rich extract from grape seeds. Food Chem Toxicol. 2002;40(5):599-607. doi: 10.1016/s0278-6915(02)00006-6

16. Bedran-Russo AK, Pereira PN, Duarte WR, Drummond JL, Yamauchi M. Application of crosslinkers to dentin collagen enhances the ultimate tensile strength.J Jiomed Mater Res B Appl Biomater.2007;80(1):268-72. doi: 10.1002/ jbm.b.30593

17. Zunino S. Type 2 diabetes and glycemic response to grapes or grape products. J Nutr. 2009;139(9):1794S-800S. doi: 10.3945/jn.109.107631

18. King M, Chatelain K, Farris D, Jensen D, Pickup J, Swapp A, etal. Oral squamous cell carcinoma proliferative phenotype is modulated by proanthocyanidins: a potential prevention and treatmentalternative for oral cancer. BMC Complement Altern Med. 2007;7:22 doi:10.1186/1472-6882-7-22

19. DuarteS, Gregoire S, Singh AP, Vorsa N, Schaich K, Bowen WH, etal. Inhibitory effects of cranberry polyphenols on formation and acidogenicity of Streptococcus mutans biofilms. FEMS Microbiol Lett. 2006;257(1):50-6. doi: 10.1111/.j1574-6968.2006.00147.x

20. Pastoriza S, Mesías M, Cabrera C, Rufián-Henares JA. Healthy properties of green and white teas: an update. Food Funct. 2017;8(8):2650-62. doi:10.1039/ c7fo00611j

21. Rice-evans CA, Miller NJ, Bolwell PG, Bramley PM, Pridham JB. The Relative Antioxidant Activities of Plant-Derived Polyphenolic Flavonoids. Free Radical Research. 1995;22(4):375-83. doi:10.3109/10715769509145649

22. ChanEWC, SohEY, Tie PP, Law YP.Antioxidant and antibacterial properties of green, black, and herbal teas of Camellia sinensis. Pharmacognosy Res. 2011;3(4):266-72. doi: 10.4103/0974-8490.89748

23. Higdon JV,Frei B. Tea catechins and polyphenols: health effects, metabolism, and antioxidant functions. Crit Rev Food Sci Nutr. 2003:43(1):89-143. doi: 10.1080/10408690390826464

24. Maruyama T, Tomofuji T, Endo Y, Irie K, Azuma T,Ekuni D, etal. Supplementation of green tea catechins in dentifrices suppresses gingival oxidative stress and periodontal inflammation. Arch Oral Biol. 2011;56(1):48-53. doi: 10.1016/j. archoralbio.2010.08.015

25. Zhu NW, Yin XL, Lin R, Fan XL, Chen SJ, Zhu YM, et al. Possible mechanisms of lycopene amelioration of learning and memory impairment in rats with vascular dementia. Neural Regen Res. 2020;15(2):332-41. doi: 10.4103/16735374.265565

26. Patil J, Reddy A, Venigalla B, Shekar K, Ravichandra C, Binoy D. Effect of different concentrations of carbamide peroxide and green tea extract on the color and shear bond strength of enamel \&A8211; an in vitro study. Endodontology. 2015;27(2):129-35. doi:

27. Paravina RD, Ghinea R, Herrera LJ, Bona AD, Igiel C, Linninger M, etal. Color difference thresholds in dentistry. J Esthet Restor Dent. 2015;27 Suppl 1:S1-9. do: 10.1111/jerd.12149

28. Schoppmeier CM, Derman SHM, Noack MJ, Wicht MJ. Power bleaching enhances resin infiltration masking effect of dental fluorosis. A randomized clinical trial.J Dent. 2018;79:77-84. doi: 10.1016/j.jdent.2018.10.005
29. Al-Maliky MA. Clinical Investigation of $940 \mathrm{~nm}$ Diode Laser Power Bleaching: An In Vivo Study.J Lasers Med Sci. 2019;10(1):33-6. doi: 10.15171/jms.2019.05

30. Bittencourt ME, Trentin MS, Linden MS, de Oliveira Lima Arsati YB, Franca FM, Florio FM, etal. Influence of in situ postbleaching times on shear bond strength of resin-based composite restorations. J Am DentAssoc. 2010;141(3):300-6. doi: 10.14219/jada.archive.2010.0164

31. Elkhatib H, Nakajima M, Hiraishi N, Kitasako Y, Tagami J, Nomura S. Surface pH and bond strength of a self-etching primer/adhesive system to intracoronal dentin after application of hydrogen peroxide bleach with sodium perborate. Oper Dent. 2003;28(5):591-7.doi:

32. Rotstein I. Role of catalase in the elimination of residual hydrogen peroxide following tooth bleaching. JEndod. 1993;19(11):567-9. doi:10.1016/S00992399(06)81288-4

33. Torres CRG, Koga AF,Borges AB. The effects of anti-oxidant agents as neutralizers of bleaching agents on enamel bond strength. Brazilian Journal of Oral Sciences. 2006;5(16):971-6. doi:

34. Nascimento GCR, Ribeiro MES, Guerreiro MYR, de Souza CruzEL, Pinheiro JJV, Loretto SC. Effect of sodium ascorbate on bond strength and metalloproteinases activity in bleached dentin. Clin Cosmet Investig Dent. 2019;11:259-65. doi: 10.2147/ccide.S209278

35. Rana R, Kaushik M, Sharma R, Reddy P, Mehra N. Comparative evaluation of effects of natural antioxidants on the shear bond strength of composite resin to bleached enamel. Indian J Dent Res. 2019;30(1):112-6. doi: 10.4103/ijdr. IJDR $397 \_17$

36. Bansal M, Kaur P, Cyriac AR, Kadian N, Jaiswal P, Rathee K. Impact of Different Antioxidants on the Bond Strength of Resinbased Composite on Bleached Enamel-An In Vitro Study.J Contemp DentPract. 2019;20(1):64-70. doi:

37. Kobakhidze GD, Vadachkoriia NR, Tkhilava NG. [Benefits of antioxidant agents' use for dental filling consequent to the endo-bleaching]. Georgian Med News. 2006(137):38-42. doi:

38. BRIGELIUS-FLOHÉR, TRABERMG. VitaminE: function and metabolism. The FASEB Journal. 1999;13(10):1145-55. doi: 10.1096/fasebj.13.10.1145

39. Kavitha M, Selvaraj S, Khetarpal A, Raj A, Pasupathy S, Shekar S. Comparative evaluation of superoxide dismutase, alpha-tocopherol, and 10\% sodium ascorbate on reversal of shear bond strength of bleached enamel: An in vitro study. Eur J Dent. 2016;10(1):109-15. doi:10.4103/1305-7456.175693

40. Manoharan M, Shashibhushan KK, Poornima P,Naik SN, Patil D, Shruthi AS. Effect of newer antioxidants on the bond strength of composite on bleached enamel. J Indian Soc Pedod Prev Dent. 2016;34(4):391-6. doi: 10.4103/09704388.191430

41. Karadas M, Demirbuga S. Influence of a short-time antioxidant application on the dentin bond strength after intracoronal bleaching. Microsc Res Tech 2019;82(10):1720-7. doi: 10.1002/jemt.23337

42. Ismail EH, Kilinc E, Hardigan PC, Rothrock JK, Thompson JY, Garcia-Godoy C. Effect of Two-minute Application of 35\% Sodium Ascorbate on Composite Bond Strength following Bleaching. J Contemp Dent Pract. 2017;18(10):874-80 doi:10.5005/jp-journals-10024-2142

43. Haralur SB, Raqe S Alqahtani N, Alhassan Mujayri F.Effect of Hydrothermal Aging and Beverages on Color Stability of Lithium Disilicate and Zirconia Based Ceramics. Medicina (Kaunas). 2019;55(11):749. doi:10.3390/medicina55110749

44. Altinci P,Durkaya P.Effects of thermocycling and various drinks on the color stability of heat-polymerized acrylic resin. J Istanb Univ Fac Dent 2016;50(3):15-20. doi: 10.17096/jiufd.28587

45. Jose P,Sanjeev K, Sekar M. Effect of Green and White Tea Pretreatment on Remineralization of Demineralized Dentin by CPP-ACFP-An Invitro Microhardness Analysis. J Clin Diagn Res. 2016;10(4):ZC85-ZC9. doi: 10.7860/ JCDR/2016/16038.7674 
46. Karemore TV, Motwani M. Evaluation of the effect of newer antioxidant lycopene in the treatment of oral submucous fibrosis. Indian J Dent Res. 2012;23(4):524-8. doi:10.4103/0970-9290.104964
47. TawfikMS,Abdel-Ghaffar KA, Gamal AY,El-DemerdashFH, Gad HA Lycopene solid lipid microparticles with enhanced effect on gingival crevicular fluid protein carbonyl as a biomarker of oxidative stress in patients with chronic periodontitis. J Liposome Res. 2019;29(4):375-82. doi: 10.1080/08982104.2019.1566243

\section{Assistant Professor Dr. Alperen Degirmenci}

(Corresponding address)

Van Yuzuncu Yil University, Faculty of Dentistry, Department of Restorative

Dentistry, Van/ TURKEY

E-mail: adegirmenci@yyu.edu.tr

Date submitted: 2020 Feb 28

Accept submission: 2020 May 25 